Andrea Althoff

Divided by Faith and Ethnicity 


\section{Religion and Society}

Edited by

Gustavo Benavides, Kocku von Stuckrad and Winnifred Fallers Sullivan

\section{Volume 62}




\section{Andrea Althoff}

\section{Divided by Faith \\ and Ethnicity}

Religious Pluralism and the Problem of Race in Guatemala 
ISBN 978-1-61451-710-8

e-ISBN 978-1-61451-508-1

ISSN 1437-5370

\section{Library of Congress Cataloging-in-Publication Data}

A CIP catalog record for this book has been applied for at the Library of Congress.

Bibliographic information published by the Deutsche Nationalbibliothek

The Deutsche Nationalbibliothek lists this publication in the Deutsche Nationalbibliografie; detailed bibliographic data are available in the Internet at http://dnb.dnb.de.

(c) 2014 Walter de Gruyter GmbH, Berlin/Boston

Printing: Hubert \& Co. GmbH \& Co. KG, Göttingen

(2) Printed on acid-free paper

Printed in Germany

www.degruyter.com 